\title{
A Review of Critical Success Factors (CSFs) For Executive Information System (EIS) Development in Education Domain
}

\author{
Ulasan Faktor Kritikal Kejayaan untuk Pembangunan Sistem Maklumat Eksekutif \\ (EIS) dalam Domain Pendidikan
}

\author{
Mahamsiatus Kamaruddin
}

IPG Kampus Pendidikan Teknik, Kompleks Pendidikan Nilai; siatus09@gmail.com

\begin{abstract}
This study reviews the critical success factors (CSFs) of executive information systems (EIS) development for education domain. EIS is the information system that can integrate internal and external information, which allows executives formulate plans, explain the indicators, determine organisation performance, mapping productivity and make strategic decision making. Although the implementation of the EIS can be complying using the standard system development life cycle (SDLC) model, the CSFs that affect its development is important to identify to the success of its initiative. Previous studies have examined various CSF to the success of EIS implementation, but explanation the significant of CSF based on the findings in education EIS development needs to discuss further. The study was accomplished through content analysis approaches based on the previous findings on CSF framework in education EIS development study done by the author. The results explained the review of CSF components discovered, (1) organisational contexts, (2) human resources, (3) development activities, and (4) EIS as a product. These findings potentially used as a reference to the continuing development of education EIS or the development of EIS in any organisation that possess management background similar as an education field.
\end{abstract}

Keywords: Executive Information System (EIS), Critical Success Factors (CSFs)

\section{Abstrak}

Kajian ini bertujuan mengulas faktor kejayaan kritikal (FKK) untuk pembangunan sistem maklumat eksekutif (SME) dalam domain pendidikan. SME adalah sistem maklumat mengintegrasikan maklumat dalaman dan luaran organisasi, yang membolehkan eksekutif merangka pelan perancangan, menjelaskan indikator, menentukan pencapaian organisasi, meningkatkan produktiviti dan membuat keputusan. Walaupun pelaksanaan SME boleh dilakukan menggunakan model standard kitaran hayat pembangunan sistem, mengenalpasti FKK yang mempengaruhi pelaksanaan SME penting menjayakan inisiatif SME. Beberapa kajian lampau telah mengkaji FKK untuk menjayakan pelaksanaan SME, namun penjelasan kepentingan FKK berdasarkan dapatan yang diperoleh untuk menjayakan pembangunan SME dalam domain pendidikan perlu dibincangkan dengan lanjut. Kajian ini dilakukan secara analisis kandungan berdasarkan kerangka kerja FKK untuk pembangunan SME pendidikan merujuk kajian penulis yang lepas. Hasil kajian ini menjelaskan secara lanjut fokus 
penggunaan FKK berdasarkan komponen (1) sumber manusia, (2) proses pelaksanaan, (3) persekitaran organisasi dan (4) produk untuk pembangunan SME pendidikan. Dapatan kajian ini berpotensi dijadikan rujukan melancarkan pelaksanaan berterusan SME pendidikan atau SME di organisasi lain yang mempunyai latar belakang pengurusan sama seperti domain pendidikan.

Kata kunci: Sistem Maklumat Eksekutif (SME), Faktor Kejayaan Kritikal (FKK)

\section{INTRODUCTION}

The use of data and information is important to assist organisations to improve action towards decisions making on planning and the management operations. The implementation of an information system (IS) which can support decision making is important in the formulation of policies effectively in order to strengthen the performance of an organisation. The Executive Information System (EIS) is a Computer-Based Information System (CBIS) which is able to transfer information from the Management Information System (MIS) and further analysis can be performed on online platform (Roldan \& Leal 2003). EIS having functionalities, provide the intelligence needed in decision making, which has many similar functions as Enterprise Resource Planning (ERP), Online Analytic Processing (OLAP) etc. (Negash 2004). The implementation of the EIS can improve the quality and quantity of information and raise the levels of work performance of executives to make strategic decision making. The EIS able to extract, filter and detect critical information of organisation, besides permitting access to various information in the form of multi-dimensional formats pertaining to the organisation business (Averweg \& Roldan 2006). Due to its importance, organisation in various domain investing in the EIS project including in educational management. Education management, investing in EIS as an effort to strengthen and improve the education management efficiency.

However, the success of the implementation of EIS does not depend only on the design and technology. Although the EIS can be realized by complying the system development life cycle and the previous research has reported the used of technology can improve the organisation management, that's only as a reference in the system development process and the technology function as the infrastructure. It cannot guarantee the success of the EIS, the EIS still carries the risk of failure and cause wastage of time of an organisation. Identified To explore further the factors which influence the implementation of the system is important to the success of the IS initiative (Norzaidi \& Intan Salwani 2008). According to Ikart (2009), studies on EIS should be focused on contributing factors that influence EIS's implementation success. The important elements are known as Critical Success Factors (CSF).

The CSF concept is able to determine the key elements to ensure the success of the implementation of the system, including how to handle issues which influence the failure or success of an IS. The CSF framework of EIS development for education domain has been discussed in previous author paper (Mahamsiatus, Rozilawati \& Aziz, 2011; Rozilawati \& Mahamsiatus, 2011). However, explanation the significant of CSF for education EIS development need to discuss further. Therefore, this study aims to discuss the identified CSFs in education EIS development. 


\section{BACKGROUND}

\section{Executive Information Systems (EIS)}

EIS is identified as the IS that having a strategic impact to organisation management. EIS is sophisticated IS that specifically developed that enables executives in the management process of an organisation. It can help in providing the simplified and concise information that allows executive to plan, monitor and control business process based on an analysis of organisation data using the computerized system (Mahamsiatus, Rozilawati \& Aziz, 2011). The development of the EIS can overcome the manual data collection which requires a long period of time, can help executives to view an organisation's situation from different perspectives and enables strategies to be formulated. The implementation of an EIS has been identified able to merge and map various internal and external information which would display data and done a comparative analysis as a whole (Mahamsiatus \& Rozilawati, 2011). The EIS is a computerized system technology designed to fulfill specific requirements of executives, to assist in management and plan the organisational strategies (Mahamsiatus, Rozilawati \& Aziz 2011). This feature useful for executives to plan the options and strategies for future actions of the organisation.

Srivihok (1999) defines an EIS as a computer system that provides for the executive information needs. Salmeron and Herrero (2005) indicate EIS is a CBIS that supports communication, coordination, planning and control functions for the organisation managers or executives. While Ikart (2005) describes EIS is a computer-based system that provides access to information requirements for senior management. It provides access to information quickly and accurately into the organized format. The system is user friendly, supported by charts, reports and drill-down facilities detailed information. This system has access to online information services and electronic mail. It is evident; EIS should have the following attributes, integrated information, serving organisation strategies/critical success factors, enhancing organisation decision making capabilities, involving organisation management and having a systematic structure and some special features.

\section{Critical Success Factors (CSF)}

The CSF concept was introduced by Rockart in the 1980s based on the Daniel study in 1970 (Caralli, 2004). CSF in EIS means the identification of components that are critical for successful implementation of EIS development process. To ensure the success of the implementation of organisation EIS, this includes the present of important components along the system implementation at before, during and after the development process. Even the system has been developed, it should continue to change or evolve over time due to the business needs. According to Rockart in Caralli (2004), CSF is defined as, key areas of activity in which favorable results are absolutely necessary to reach goals, key areas where things must go right for the business to flourish. CSF is the 'factors' that are 'critical' to the 'success' that should receive attention to ensure the success of any initiative in organisation management. In this study, CSF is meant related to the development of an EIS in the 
education domain. The CSF and the framework of CSF for education EIS development has been proposed in author previous paper 'A Framework of Successful Executive Information System Development for Education Domain’ (Mahamsiatus \& Rozilawati, 2011).

From the analysis of previous research and verified by field study (Mahamsiatus, Rozilawati \& Aziz, 2011; Rozilawati \& Mahamsiatus, 2011), four common themes CSF was discovered, people, process, product and environment which each theme comprises several items:

- Environment - is the organisation and managerial factors that affect the EIS development.

- People - are human resources who are involved directly or indirectly in executing EIS initiatives.

- Process - is defined as activities performed during system development and during the upgrading or maintenance the system.

- Product - is the system itself, which produced by the process.

\section{METHODOLOGY}

This study was carried out using qualitative research using a content analysis approach based on the previous research finding done by the author that engage the respondents involved in the education EIS development from three education agencies (Mahamsiatus \& Rozilawati, 2011). The reliability test of the findings which has been done based on Kappa or k value, indicate the CSF for the success of education EIS development at the level 'very good'. The steps involved in this study are as follows: Step 1: Access the interview transcribed findings and identify research problem

Step 2: Applying content analysis approach to review the identified CSF

Step 3: Compare the findings across transcripts

Step 4: Propose the findings

\section{FINDINGS}

As the study concern the EIS development in the education domain, the following discussion, review the significant of respective CSF that has been identified.

\section{Environment (organisation setting)}

Environment factor involves the management practices to coordinate EIS development so that the system can be continuously used. Management needs to acquire and plan allocation for the EIS project ongoing, conduct awareness programmed and identify the changes of information needs. These activities cannot be achieved by management solely. Cooperation in terms of information sharing culture and positive attitude towards the system should be obtained. The committees and parties involved in the project have to consider educational strategic plans, Key Performance Indicators (KPI) and IS development Standard Operating Procedures (SOP) as well as project management policies during the process. 
Management practices: This factor related to organisation management in manipulating the resource to achieve the plan/policy factor and address the organisational politics and culture issue that influence the success of EIS development. The management practices factor (financial, system awareness, IS sources) significant:

- To coordinate financial allocation to achieve continuity the EIS development

- To ensure the investment in ICT project (EIS) is carried out efficiently and effectively

- To create understanding among organisation about the applicable IS used in the education management related to EIS development

- To determine the organisation's strengths, weaknesses, opportunities and threats related to EIS development

- To determine the function of EIS in educational management, identify the gaps, potential of EIS in organisation transition, identify information from IS available for EIS and assess unmet criteria that affect the implementation of EIS

- To evaluate the organisation technology used and effectiveness the current ICT infrastructure used to meet the EIS development

- To formulate the EIS development strategy that applies to achieve the organisation goals

- To evaluate the extends of current organisation IS, including the modules that has been developed, how the link between the IS and availability IS documentation to determine the scope of EIS development

- To determine a strategy using current organisation IS to EIS development

- To designation the procedures to maps and integrate the data from IS to EIS for management needs

- To determine the availability method and data collection techniques to EIS development

Politics and culture: This factor related to the acts among organisation to the success of EIS development to achieve the organisation plan/policy. The politics and culture factor (cooperation in information sharing, attitude, organisation culture towards projects) significant:

- To understand organisational culture related to EIS development

- To understand the current IS management within organisation

- To address politics and organisation culture issues that exist related to EIS development

- To create involvement among organisation to ensure the success of EIS development

- To intensify the cooperation among organisation in the implementation of EIS development

- To create attitude changes towards the EIS development

Plan/Policy: This factor involves the activities that should unite interconnected between the organisation ICT strategic planning main goals and policies to achieve the education management setting related to the EIS development. The plan/policy factor (education strategic plan, KPI, SOP, project management) significant:

- To create same understanding among organisations about the education ICT strategic planning goals and objectives 
- To create clarity among organisation the importance and the benefit of the project to improve the implementation of ICT initiatives towards to strengthen the educational management

- To create clarity about implementation of ICT initiative such as EIS will impact the organisation management in terms of organisation information sharing culture and workflow procedures in education management

- To create a steadiness between the successful education ICT strategic planning and implementation of EIS development

- To be as a guidance among organisations which lack with the experience about the EIS development

- To put as a benchmark in the EIS development with taking into account the education ICT planning

- To create awareness about EIS development requires a particular project management framework

- To disclose the development of EIS needs particular committee (team) that can do the strategic role to achieve the EIS development process workflow

\section{People (human resources)}

People factor includes the organisation's top management or executives, EIS development team and education personnel. These parties need to understand the purpose and importance of an EIS project to improve the organisation planning and decision making. The EIS project cannot succeed without strong support and participation from executives, financial allocation and other tangible resources. The support is necessary to deal with organisation political issue and resistance towards the system. Technical skills are needed for the operational part, whereas interpersonal skills are required for getting right requirements and obtaining users' acceptance. The development team is responsible to plan, develop and maintain the technical infrastructure and manage the system operations. The educational personnel responsible to manage the sources of information which their primary contribution is to provide adequate and correct data into the system timely. They need to manage the information properly so that it becomes reliable. Reliable information leads to meaningful analysis and thus enhances the decision making process by the executives.

Executive/top management: Executives have the responsibilities in organisation management. Executives are the policy breaker and policy maker in the organisation which is the EIS end user. The executive/top management factor (support and involvement) significant:

- To develop executives tendency using ICT in organisation management

- To disclose clarity to executives about the issues has to addressed to the success of EIS development in organisations

- To assess human resource and ICT infrastructure needed in EIS development

- To create understanding about the EIS project is to the benefit of the executive

- To create openness of executive to accept the EIS implementation and discuss the idea about the system requirements

- To gain executive support that is essential in the success of the implementation of EIS initiative

- To decide the EIS features to develop collectively 
Development team: Development team is the EIS committee or IS staff, which responsible to formulate and implement the EIS development continuously. They have to complete the EIS work schedule and workflow activities, including managing EIS development risks and resolve any issues arising. The development team factor (technical and interpersonal skills) significant:

- To clarify the team in implementing EIS development initiatives successful

- To assess development team requirements in EIS development

- To clarify the team strategy in EIS development

- To align the team direction in EIS development with organisation plan/policy

- To align the organisation ICT infrastructure, technology used, technology capacity, tools using in a development organisation IS, network and technology protocols in EIS development

- To evaluate organisation IS management by specifying the current IS used, the potential changes, risk, IS management, IS staff, data administrator, database, IS security apply and the role among management level in EIS development

- To create a platform between all parties towards the EIS development

- To create autonomy among team members to discuss the understanding and willingness to accept others views about the EIS development

Educational personnel: Educational personnel are the officer who's in charge the IS at their respective management level. Educational personnel have to do the integrity data checking before it's integrate into EIS database. The educational personnel factor (information management) significant:

- To diversify the use of data from IS in order to enhance the effectiveness of organisation management

- To create a standard procedure to increase the efficiency of organisation IS before its link to EIS database

- To improve knowledge and IS personnel skills in data management for strategic planning of organisation

. To apply standard synchronies data extraction and data management of IS at every management level

- To create commitments among IS personnel in EIS development

- To create openness among IS personnel about EIS development

\section{Process (development activities)}

Process factor includes the planning and execution activities that happen throughout the EIS development. The planning process must take into account the development lifecycle as well as hardware and software infrastructure available in organisations. The execution process has to synchronize data extraction and data management activities for various information sources.

Planning process: Planning process involves the activities to implement the EIS development continuously, including identifying the hardware and software infrastructure to implement the EIS. The planning process factor (development activities (methodology, system requirement, system maintenance, monitoring), hardware and software infrastructure) significant: 
- To define EIS development project is accordance with the various current in the organisation

- To create knowledge and skills in EIS development

- To handle any change management plan cause of the request or issue arise during the EIS development

- To the successful between EIS development and any technical or social issues in organisation

- To achieve integrated features and function in EIS design and development strategies that meet the organisation needs

Execution process: Execution process involves the activities during the EIS development which the system should have the integrated features and functions. The execution process factor (data extraction (periodically, adequate, correct), data management) significant:

- To map EIS development strategy with organisation needs

- To create effective strategies in EIS development to support organisation management

- To plan, alternative strategy in EIS development, pertaining what is the most important, what can be done and cannot, that need further discussions

- To control the output of EIS development

- To ensure EIS design can be run efficiently and effectively to meet organisation goals

\section{Product (education EIS)}

The product is the developed EIS that contains integrated features and functions concerning education business. The product factor significant for:

- To develop EIS that meets the users' needs continuously

\section{CONCLUSION}

Decision making is important to the organisation for a short-term or long-term planning. EIS helps managers understand the non-structured problems and provide better analysis before a decision made to assist the organisation management. The use of the information for the purpose of organisation strategic planning becomes very important because informative data should be done in a short period and are at the fingertips. Data need to be analysed to be informative that could explain the scenario happens in an organisation. Development of EIS identified to increase the efficiency of the management of education.

The CSF framework of EIS development in education domain has been formulated, contain four main components, namely organisation, human resources, implementation process and products (EIS). This paper review further the respective CSFs in EIS development in education domain. Each factor has a different impact on the success of EIS development. Future paper has to share the evaluation and use of the framework in the development of education EIS. These findings potentially used as a reference to the continuing development of education EIS or the development of EIS in any organisation that possess management background similar as an educational field. 


\section{REFERENCES}

Averweg, U.R. \& Roldan, J.L. (2006). Executive information system implementation in organisation in South Africa and Spain: a comparartive analysis. Computer Standards \& Interfaces. 28(6), 625-634.

Caralli, R. A. (2004). The critical success factor method: establishing a foundation for enterprise security management. Software Engineering Institute, Carnegie Mellon, Pittsburgh. Retrieved from http://www.sei.cmu.edu/repo

Ikart, E. M. (2005). Critical success factors for executive information systems usage in organisations. PhD Theses, The University of Wollonggong.

Mahamsiatus K., Rozilawati R. \& Aziz D. (2011). Critical success factors of executive information systems development for education management-A preliminary investigation. Proceedings of the 2011 International Conference on Electrical Engineering and Informatics, ICEEI 2011, 1-6.

Mahamsiatus, K. \& Rozilawati, R. (2011). A framework of successful executive information system development for education domain. America Journal of Applied Sciences. 8(10), 997-1003.

Negash, S. (2004). Communication of The Association for Information Systems. Business Intelligence. 13(15), 177-195.

Noizaidi M.D. \& Intan Salwani M. (2008). Information technology (IT) management models an introduction. Shah Alam: Penerbit Universiti Teknologi MARA (UITM).

Rozilawati, R. \& Mahamsiatus, K. (2011). Executive information system (EIS) implementation for education management - a conceptual framework. (pp. 420-427). $5^{\text {th }}$ European Conference on Information Management and Evaluation.

Salmeron, J. L. \& Herrero, I. (2005). An AHP-based methodology to rank critical success factors of executive information systems. Computer Standard \& Interfaces. 28, 1-12.

Srivihok, A. (1999). Understanding executive information systems implementation: an empirical study of EIS success factors. Proceeding of $32^{\text {nd }}$ Hawaii International Conference on System Sciences.

Roldan, J.L. \& Lead, A. (2003). A validation test of an adaption of the DeLone and McLeans Model in the Spanish EIS field. Retrieved from http://pdf.aminer.org/000/326/965/a_partial_test_and_development_of_the_delone_and_mclean.pdf 